Geology, Geophysics \& Environment • 2012 • Vol. 38 • No. 2 • 279-280

http://dx.doi.org/10.7494/geol.2012.38.2.279

\title{
PROF. DR EDUARD A. VYSOTSKY (1943-2011) - WSPOMNIENIE
}

\section{Memories of Prof. Dr. Eduard A. Vysotsky (1943-2011)}

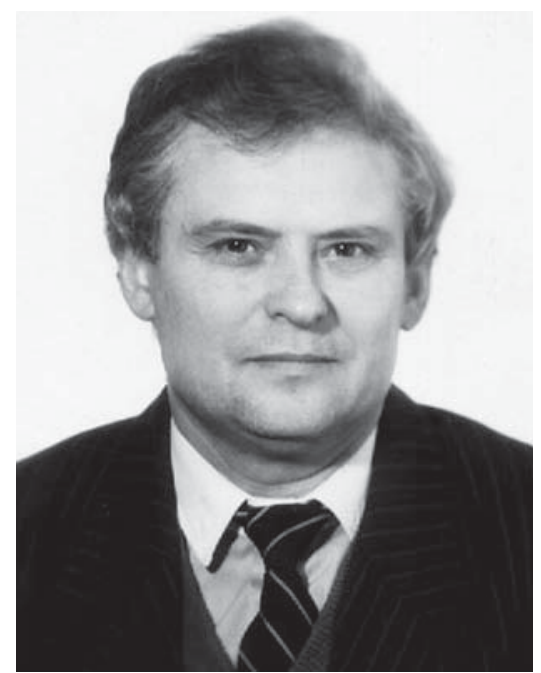

Profesor Eduard A. Vysotsky, doktor nauk geologicznych i mineralogicznych, członek Białoruskiej Akademii Górniczej, wybitny geolog białoruski i znakomity specjalista w zakresie badań utworów ewaporatowych, zmarł 10 maja $2011 \mathrm{r}$.

Eduard A. Vysotsky urodził się 13 sierpnia 1943 r. w Witebsku. W 1965 r. ukończył z wyróżnieniem studia na Wydziale Geografii Białoruskiego Uniwersytetu Państwowego i rozpoczął pracę w charakterze młodszego pracownika naukowego w oddziale stratygrafii i paleontologii Instytutu Nauk Geologicznych Ministerstwa Geologii ZSRR; dużą rolę w jego rozwoju naukowym odegrali wtedy A.V. Fursenko (członek-korespondent Akademii Nauk, który był jego kierownikiem), V.K. Golubtsov, S.A. Kruchek i G.I. Kedo. W latach 1967-1968

E.A. Vysotsky był zatrudniony w Instytucie Nauk Geologicznych jako inżynier-konstruktor; uczestniczył wtedy w badaniach osadów solonośnych i wystąpień soli potasowych w niecce prypeckiej, a także w przygotowaniu dokumentacji poziomów soli potasowych w powstających szybach 3. Soligorskiego Kombinatu Potasowego (obecnie: 3. Zarząd OTA „Belaruskaliy”). W tym czasie znaczący wpływ wywarli na niego - jako geologa i naukowca wybitni białoruscy geolodzy solni, tacy jak M.I. Lupinovich, V.Z. Kislik i D.M. Yeroshina.

W 1969 r. Eduard A. Vysotsky rozpoczął studia podyplomowe i badania pod kierunkiem naukowym prof. M.P. Fivega, wybitnego geologa solnego z Wszechzwiązkowego Instytutu Badawczego Geologii (VNIIG) w Leningradzie, a w 1971 r. obronił rozprawę doktorską nt. geologii warstw solonośnych północnej części niecki prypeckiej, wyjaśnienia warunków ich powstawania oraz poszukiwania ich wystąpień, uzyskując stopień naukowy kandydata.

W latach 1972-1988 E.A. Vysotsky był pracownikiem Zakładu Stałych Surowców Mineralnych Białoruskiego Instytutu Naukowo-Badawczego Geologii (BelNIGRI), początkowo na stanowisku młodszego pracownika naukowego, a od 1973 r. - starszego pracownika 
naukowego. Uczestniczył wtedy w rozwiązywaniu wielu ważkich problemów dotyczących geologii ewaporatów, takich jak korelacja osadów solnych i poziomów soli potasowych, problemy tektoniki, litologii, paleogeografii i mineralogenezy, a także brał udział w ocenie możliwych zasobów surowców niemetalicznych i w kompilacji map geologicznych. Na podstawie rekomendacji przygotowanych przez E.A. Vysotsky’ego i dwóch innych członków zespołu (V.Z. Kislik i N.S. Petrova) wyróżniono kilka perspektywicznych obszarów soli potasowych (Zhitkovichi, Kopatkevichi, Smolov, Drozdov, Svetlogorsk) w obrębie niecki prypeckiej oraz odkryto złoże soli potasowej Okriabr. Twórcza współpraca z kolegami z BelNIGRI oraz z akademikiem R.G. Garetskym zaowocowała kilkoma ważnymi monografiami: Dewońskie formacje solonośne niecki prypeckiej (1982), Sole potasowe niecki prypeckiej (1984) oraz Potasonośne baseny świata (1988). Ukazanie się tych dzieł w bardzo znacznej mierze przyczyniło się do rozwoju wiedzy nt. struktury, składu materialnego i warunków sedymentacji osadów solonośnych niecki prypeckiej oraz warunków halogenezy w starych strefach ryftowych. Synteza licznych danych na temat basenów potasonośnych na świecie pozwoliła na sformułowanie głównych prawidłowości powstawania takich basenów w fanerozoiku; wyniki tych badań spotkały się z olbrzymim uznaniem wśród geologów ZSRR.

W latach 1989-1993 E.A. Vysotsky pracował w laboratorium naukowo-badawczym Białoruskiego Uniwersytetu Państwowego. Był wtedy zaangażowany w badania problemów paleogeomorfologii, paleotektoniki, analizy litofacjalnej i roponośności dewońskich kompleksów śródpolnych i nadsolnych niecki prypeckiej. Wynikiem prowadzonych wtedy prac było wyróżnienie przez E.A. Vysotsky’ego wraz ze współautorami stref potencjalnych nagromadzeń ropy naftowej i gazu ziemnego w skałach węglanowo-siarczanowych i terygenicznych utworów halitowych w górnych warstwach solonośnych.

W 1993 r. Eduard A. Vysotsky rozpoczął pracę jako główny pracownik naukowy w Zakładzie Stałych Surowców Mineralnych BielNIBRI, koncentrując się na przygotowaniu rozprawy umożliwiającej uzyskanie stopnia doktora nauk; stopień ten uzyskał w 1997 r. na podstawie rozprawy Ewaporaty Białorusi: warunki sedymentacji i litofacje. W tym też czasie razem z L.A. Demidovichem i Yu.A. Dereviankinem przygotował i opublikował podręcznik dla studentów pt. Geologia i surowce mineralne Republiki Białorusi (1996).

Od 1998 E.A. Vysotsky był profesorem - cenionym i lubianym przez studentów - Katedry Geologii Dynamicznej Wydziału Geologii Białoruskiego Uniwersytetu Państwowego, wykładając przedmioty dotyczące poszukiwania złóż surowców, genezy złóż surowców, złóż surowców energetycznych, metali i surowców niemetalicznych, a także przygotowując i publikując podręczniki z zakresu tych (i innych) przedmiotów. W 2000 r. otrzymał tytuł naukowy profesora w dziedzinie geologii. Łączył swoją aktywność pedagogiczną z badaniami naukowymi - przygotował z kolegami i opublikował trzy ważkie monografie: Złoża soli potasowych Białorusi: geologia i efektywne zarzadzanie (2003), Złoża mineralne Białorusi (2004), Technologie satelitarne w geodynamice (2010), a także Mapę zasobów mineralnych Republiki Białorusi w skali 1:500 000 (2004). Dwaj jego uczniowie (T.A. Baikova i V.E. Kutyrlo) uzyskali stopień kandydata nauk geologicznych i mineralogicznych.

E.A. Vysotsky jest autorem przeszło 240 publikacji, w tym sześciu monografii i siedmiu podręczników; niektóre z tych publikacji ukazały się w czołowych czasopismach ZSRR (,Sovetskaya Geologiya”, „Geologiya nefti i gaza”, „Doklady AN SSSR”, „Bulletin of the 
Moscow Society of Naturalists”) oraz prestiżowych tytułach międzynarodowych (np. „International Geological Review”, „Sedimentary Geology”). Uczestniczył w ponad 40 projektach badawczych i rozwojowych, m.in. w międzynarodowym projekcie INTAS-Belarus-97, oraz kilku białorusko-polskich projektach poświęconych studiom ewaporatów dewońskich i permskich Białorusi i Polski, pod kierownictwem naukowym akademika A.A. Makhnacha i prof. T.M. Peryta.

W 2006 r. E.A. Vysotsky opublikował książkę pt. Moje notatki z podróży, która opowiada o jego życiu, pracy i podróżach, w tym zwłaszcza o jego wizytach w polskich kopalniach soli (Wieliczka, Bochnia i Kłodawa), o jego miłości do rodzinnej Białorusi. Eduard Vysotsky ciepło pisze o swoich przyjaciołach, kolegach i innych osobach poznanych podczas prowadzonych przez niego badań, spotykanych w pracy i w trakcie podróży. Był jednym z inicjatorów i głównych autorów monografii Geolodzy i inżynierowie górniczy Białorusi (2008) - oryginalnej książki pamiątkowej, będącej świadectwem jego głębokiego szacunku dla geologii i zajmujących się nią ludzi.

Eduard A. Vysotsky - wybitny uczony i pedagog, świetny gawędziarz, człowiek o wspaniałej osobowości - pozostanie na zawsze w naszej pamięci.

R.G. Garetsky, A.A. Makhnach, V.N. Gubin, S.A. Kruchek, N.S. Petrova 